\title{
Nurturing the Literate Mind through Group Interaction among Literary Thinkers
}

\author{
TINA ABDULLAH \\ Universiti Teknologi Malaysia, Malaysia \\ tinaabdullah@utm.my \\ ZAIDAH ZAINAL \\ Universiti Teknologi Malaysia, Malaysia \\ ABDUL HALIM ABDUL RAOF \\ Universiti Teknologi Malaysia, Malaysia
}

\begin{abstract}
Conventional classroom discourse structure that nurtures literacy through the scientific way of thinking is argued to limit personal engagement and exploration of alternative thinking processes among literary thinkers. In nurturing literacy for the literate mind, this study investigated how the literary way of thinking through group interaction can become a powerful alternative avenue to complement the established scientific way of thinking. Based on the Reader Response and Envisionment Building theories, participants were given the freedom to wander and become personally involved in group interactions advancing thinking about meaning through exploring horizons of possibilities. Through peer-led group discussions, this case study examined a group of 31 undergraduate learners who discussed a short story as part of a literature course. The overall findings show that when given the freedom to explore horizons of possibilities through group interactions, the participants demonstrated personal engagement and the ability to explore different thinking processes. Among the common themes observed were that participants shared personal recalling of facts or literary devices, contemplated personal interpretations of meaning, discussed the personal evaluation of the text, expressed doubts or misunderstandings, made personal connections or extended the imaginary world. It may thus be concluded that to nurture the literate mind, the literary way of thinking should complement the scientific way of thinking to promote different thinking processes and personal engagement. Opportunities to explore horizons of possibilities through group interactions support literacy in literature classrooms.
\end{abstract}

Keywords: the literate mind; literary thinking; horizons of possibilities; group interaction; literature instruction

\section{INTRODUCTION}

The notion of the Literate Mind is described as literacy among people who are "rich thinkers and language users, good discussants and learners...who can manage well in life and society" (Langer, 2002, p. 3). Literacy, which is commonly referred to as the ability to read and write, in this case, has been extended to mean 'being educated' (Gough, 1995; Rosenberg, 2019). This carries the idea of being "competent or knowledgeable in certain specialised areas" (Barton, 2007, p. 19) or as having "a particular set of social practices that a particular set of people value" (Harste, 2003, p. 8). Literacy for the literate mind, therefore, encompasses a wide range of definitions that may include 1) literacy as an autonomous set of skills; 2) literacy as applied, practised and situated; 3) literacy as a learning process; and/or 4) literacy as text (Education for All Global Monitoring Report UNESCO, 2006, p. 148).

The infinite ways of how literacy is understood imply its vital role for survival in today's world and demonstrate its need in the nurturing and development of mature and complex minds for shaping a sustainable literate community. Since literacy is perceived as vital for nurturing the literate mind, this evidence suggests its contribution in life, at work and within the society (Zuhana, Wong \& Shameen, 2014: Tatum, 2019) as it "involves how people think, 
and learn, and change and how society changes as a function of the changes in its people" (Langer, 1986, p. 2).

Nevertheless, many literacy programmes expose learners to the practice of a scientific way of thinking that emphasises literacy through reading and writing about factual knowledge, logical reasoning and critical thinking (Rosenblatt, 1978; Barnes, 2010; Langer, 2011). Through this modelled way of thinking, literacy involves knowledge building about the real world, providing concrete reasoning from observable and measurable truth and using critical thinking to engage in higher-order synthesis or analysis of facts (Bruner, 1986; Khamkhong, 2018). Though this way of thinking is well accepted in dominating literacy advancement in most fields, it is not the only means for nurturing the literate mind (Tytler \& Prain, 2010; Simpson, Mercer \& Majors, 2010; Langer, 2011).

For literacy in literature classrooms, reading and writing about factual knowledge and logical reasoning would adopt the efferent stance and as such may not guarantee the development of well-rounded literary thinkers (Rosenblatt, 1978). Conventional literature classrooms that take on this scientific way of thinking, do not only emphasise fixed analysis and evaluation of meaning but often adopt classroom discourse structure that promotes discussions of logical argumentation. The practice is argued to limit personal engagement and exploration of other thinking processes like imaginative or creative thinking (Rosenblatt, 2005; Simpson, Mercer \& Majors, 2010; Langer, 2011). This is especially problematic in literature instruction. This discourse structure, also known as the Initiation, Response and Evaluation (IRE), prompts specific answers (Smith, 2004; Barnes, 2008; Friend, 2017) that restricts opportunity for literary thinkers to explore the aesthetic stance (Rosenblatt, 1978), which supports exploration into personal perspectives and engagement through the literary way of thinking (Langer, 2011). Literature instruction that nurtures literate minds should consider meaning as fluid using the efferent and aesthetic stances. Furthermore, opportunities to nurture thinking and engagement should encourage the marriage of scientific and literary ways of thinking.

These developments should be nurtured through student-centred discourse structures (Barnes, 2010) like group interactions. Group interactions are important vehicles for exploring different ways of thinking as learners can explore and exchange personal thoughts and feelings about literature (Nystrand, 2006; Soter, Wilkinson, Murphy, Rudge, Reninger and Edwards, 2009). Incorporating group interactions is also important to learn more about the processes of encouraging and nurturing literacy for literate minds (Nystrand, 2006; Barnes, 2010; Langer, 2011; Johnston, 2020). This study sought to examine the group interaction patterns into thinking and personal engagement among literary thinkers when they were given the freedom to engage in what Langer (2011) identified as 'exploring horizons of possibilities' about a short story through peer-led group discussion.

\section{LITERATURE REVIEW}

In presenting how the literate mind can be nurtured through group interactions, this section introduces the idea of 'exploring horizons of possibilities' before providing an overview of the Envisionment Building and Reader Response theories as the framework for this article. The section then discusses the potentials of group interaction functioning as a vehicle for nurturing literacy through the literary way of thinking.

Exploring horizons of possibilities "can be thought of as an open-ended search, a reconnaissance mission where we are after something, but don't know exactly what. It is an "act of discovery" (Langer, 2011, p. 28). The process promotes openness and inquiry where "we use what we have gathered from life and literature to explore emotions, relationships, 
motives and reactions, calling on what we know, or imagine, it means to be (or not to be) human" (Langer, 2011, p. 32). When the mind is free to explore horizons of possibilities, the focus is on learners' experience in exploring meaning. When this happens, the meaning becomes fluid and not fixed (Langer, 2011; Rosenblatt, 1978; Barnes, 2008). Thinking about literature becomes vibrant, evocative, intimate and goes beyond factual details and logic. At this point, the text no longer bears its meaning. The mind influences the development and value of the text, which in turn makes it meaningful and alive to the person reading it. Hence, exploring horizons of possibilities is vital for the growth of literary thinkers.

The Envisionment Building theory presents the idea that when literary thinkers observe meaning through facts and logic, the scientific way of thinking is adopted. This limits exploration into horizons of possibilities as well as a personal engagement with literature. Langer (2011) proposed that the literate mind should be nurtured through both the scientific and the literary ways of thinking. She explained that literary way of thinking

is essentially one of exploration, where uncertainty, and hence open-mindedness, is a normal part of the
response and newfound possibilities provoke other possibilities. In a literary experience, we consider different
perspectives, feelings, intentions, life situations, eras, cultures, and other possibilities and their implications
in our quest for the "real" story; we often create scenarios as a means of exploration.

(Langer, 2011, p. 28)

Thus, observing meaning in literature through exploring horizons of possibilities opens opportunities to venture into alternative thinking processes about literature. This is valued to nurture the literate mind.

Likewise, in the Reader Response theory, Rosenblatt (1978) postulated that when literary thinkers read and observe meaning in literature as fixed, they explore logical and critical thinking through the efferent stance that has also been denoted as the paradigmatic mode (Bruner, 1986). In this stance, "attention is centred predominantly on what is to be carried away or retained after the reading" (Rosenblatt, 1988, p. 5). Meanwhile, when learners explore literature, they should also adopt the aesthetic stance or also identified as the narrative mode (Bruner, 1986), as they envisage and activate affective senses (Karolides, 2020) such as emotion, imagination and visualisation which are important in nurturing the mind to become active, creative and imaginative. When this happens, Rosenblatt $(2005$, p. 63) described it as a "living through" experience. She also reminds us that in literature "meaning does not reside ready-made in the text or the reader, but happens during the transaction between reader and text" (Rosenblatt, 1988, p. 4).

Both theories champion the active role of literary thinkers in exploring horizons of possibilities and recognise meaning in literature as fluid. Thinking about literature is perceived to go beyond logic into exploring personal meanings and responses using scientific and literary ways of thinking. The opportunity to construe personal meanings encourages the literate mind to wander and contemplate different explanations as to why things are the way they are in the textual world. In this dynamic state, the literate mind according to Howard (2010, p. 54) would be utilising "certain pools of experience, knowledge and feelings" and becomes progressive, complexed, immersed and unbounded. The different ways of interpreting and responding to shreds of evidence and ideas presented in texts are vital (Marlia, Zuhana \& Ihsan, 2016) in exploring horizons of possibilities to nurture literacy for the literate minds.

Thinking about literary texts has the power to move emotions and make learners experience the textual world as if it is part of reality. Nonetheless, Rosenblatt (1978) and Turner (1996) cautioned that when literary texts are explored privately, very seldom does one openly express or share personal experiences of exploring horizons of possibilities in thinking about texts. Even when literary texts are discussed, for instance in the classroom, the opportunity to share these private moments may not be intensely done due to various hurdles such as limitation of time, size of the class, reading issues or meeting assessment needs (Cho \& Krashen, 2020). 
Regardless of the challenge, literature classrooms that adopt the whole class discussion discourse structure, also known as the IRE, give limited room to advance meaning (Smith, 2004; Nystrand, 2006; Barnes, 2008; Friend, 2017).

The discourse structure that promotes the scientific way of thinking has been acknowledged to support instructors' role in orchestrating the learning process (Aukerman, Johnson \& Schuldt, 2017) using the IRE discourse structure (Barnes, 2008). Through this discourse structure, teaching and learning would usually be monologic (Tan, Tee \& Moses, 2017) or one way where the instructor controls learners' involvement in the process of shaping meaning and would predominantly be about identifying literary elements and arriving at the modelled analysis or fixed meanings that are predetermined or supplied (Rosenblatt, 1978). The structure focuses on factual details and class discussions of modelled critical analysis which limits learners' ability to interact and become personally engaged in the learning process (Barnes, 2008). It also confines the ability to share possible alternative meanings that may be done through dialogic interactions like in group discussions (Teo, 2019; Reynolds, 2019). The structure is also argued to provide a minimal opportunity for expressing aesthetic appreciation or personal sense of the text (Rosenblatt, 1993) and limitedly supports "the development and cross-fertilisation of ideas" (Smith, 2004, p. 416).

The circumstance is criticised to limit the engagement of learners in the learning process (Karolides, 2020), which in essence is fundamental for the development of the literate mind. This probably happens because it would be easier to address and evaluate concrete factual details apparent in literary texts rather than dealing with abstract or subjective matters not easily measured, expressed or viewed similarly by everyone (Rosenblatt, 1993). According to Beach, Enciso, Harste, Jenkins, Raina, Rogers, Short, Yoo, Wilson \& Agbaw (2009),

\footnotetext{
to develop a critically literate citizenship, one that can unpack the systems of meaning that operate in texts to position readers in particular ways...we need to support learners in becoming consciously aware of the systems of meaning that operate in text. Learners do this by taking multiple perspectives, becoming reflective (using themselves and others to outgrow themselves), and engaging in inquiry (not taking things at face value by always looking further and taking active responsibility for what it is they currently know). These stances have to take root as dispositions or habits of mind for readers in the $21^{\text {st }}$ century.

(p. 142)
}

Alternatively, proponents of the value of 'talk', in this case through group interactions, have paved a way to advance exploration in horizons of possibilities (Barnes, 2010; Simpson, Mercer \& Majors, 2010). They suggested the use of this discourse structure for the development of literacy (Chi, 2012; Douglas, Barnett, Poletti, Seaboyer \& Kennedy, 2015). In this case, the freedom to navigate and share thinking and response through exploring horizons of possibilities should inspire the minds to explore the use of both literary and scientific thinking processes. Group interactions not only promote exploration and development of personal engagement with literary texts (Rosenblatt, 2005; Langer, 2011; Karolides, 2020) but also provide a conducive and productive platform for nurturing the minds (Almasi, 1995; Nystrand, 2006; Daniels, 2002; Heller, 2007; Soter et al., 2009; Howe, 2013). Thus, the minds should be able to become active and critical in learning about literature. While exploring horizons of possibilities encourages the adoption of the efferent and aesthetic stances through the use of literary and scientific ways of thinking, group interactions nurture the literate minds in literature classrooms. 


\section{METHODOLOGY}

To examine how the literate mind can be nurtured, this section describes the methodology utilised in the study. It provides an understanding of the chosen context, participants, instrument and procedure used. It also provides a summary of the short story and explains how data were encapsulated and examined.

A case study was conducted in a university setting. The sampling technique used was purposive among a group of 31 second-year Teaching of English as Second Language learners who were the only ones at the university who studied literature. They had similar exposure and experience in reading different literary genres and were enrolled in a literature course at the time data were collected. As other programmes offered are based on the science and engineering fields, it was desirable to depict how the participants explored horizons of possibilities through group interactions. The group interactions centred on short stories that were read across a dominant scientific academic community.

Data collection took place over one semester. Initially, the class was instructed to form groups of three to four. The class participants were told to engage in peer-led group discussions concerning four short stories. The groups went through a practice session with the first short story. The instructor who was one of the researchers modelled the process of exploring horizons of possibilities with the participants. They were told to discuss, with no coercion and constraint, on parts or issues that reside close to their heart. As such, interruptions and facilitation on the discussions were minimised. All groups spent about 30 to 60 minutes on the discussions.

The discussion of the second short story that took place a week after the practice session was used as the data for this article. The short story is entitled Compare and was written by a local writer named Yeo Gim Suan (2009). Compare was specifically chosen for its length, readability level, and familiar themes. The short story is about 2 pages in length and has a familiar local and cultural settings. The plot that is told by a third-person narrator focuses on the life of a character named Joshua. He is an undergraduate student who happens to be in his second year just like the participants in this study. In the story, he experienced the pressure of being constantly compared to his sister and friends by both his parents. His mother Sarah also feels stressed when her husband compares her to other women and when her friends compare her baking skills with theirs. At the end of the story, both parents met with a tragic accident.

The data from eight recorded peer-led group discussion sessions were transcribed, qualitatively categorised, and analysed based on thematic analysis. Specific emerging themes based on the group interactions about exploring horizons of possibilities were noted. After the data were encapsulated and classified according to specific patterns, a trained inter-rater analyst confirmed the data analysis. This was done to address trustworthiness. Specific examples of excerpts that illustrate the common patterns of horizons of possibilities from the eight group discussion sessions were selected for the writing of this article. Pseudonyms were created for all participants in all excerpts.

\section{RESULTS}

For a clear instance of how exploring horizons of possibilities through peer-led group discussion of a short story can nurture an important facet of the literate mind, this section demonstrates the common thinking and personal engagement patterns identified.

Through the discussions of the eight groups, it was discovered that most groups shared personal recalling of facts or literary devices, contemplated personal interpretations of meaning and discussed the personal evaluation of the short story. Most groups also expressed doubts or 
misunderstandings, made personal connections or extended the imaginary world. The following four excerpts demonstrate the emerging common patterns.

The following excerpt was from the initial discussion of Group One. The four members had described the guitar in the short story and how the guitar was connected to other characters. They also explored their connections to the text:

EXCERPT 1. Discussion by Group One on the literary element

\begin{tabular}{|c|c|c|}
\hline 1 & Ana: & OK wait what's the symbol of the guitar? \\
\hline 2 & June: & Symbol? Like music? \\
\hline 3 & Ana: & The guitar \\
\hline 4 & Jo: & Good symbol? \\
\hline 5 & Sue: & Symbolise grandpa \\
\hline 6 & June: & Oh ya the grandpa \\
\hline 7 & Ana: & What do you think of the guitar? \\
\hline 8 & June: & $<$ LAUGH $>$ \\
\hline 9 & Jo: & Where the guitar? \\
\hline 10 & June: & There, the last part \\
\hline 11 & Jo: & Ya lah, got guitar la \\
\hline 12 & Ana: & Last part it says that he played the guitar \\
\hline 13 & Jo: & Yeah, then? \\
\hline 14 & Ana: & This part also it said that something about the guitar \\
\hline 15 & Sue: & Oh the guitar as a companion \\
\hline 16 & June: & Guitar, flashback \\
\hline 17 & Jo: & Don’t know \\
\hline 18 & Ana: & For him the guitar// \\
\hline 19 & Jo: & //symbolises// \\
\hline 20 & Ana: & $\begin{array}{l}\text { //the way he expresses his feelings that when he's down he plays } \\
\text { and then he remembers what his grandma said } \\
\text { Yes, that's what I think ah. every time he feels sad, he plays }\end{array}$ \\
\hline 21 & June: & What do you do? \\
\hline 22 & Sue: & Yeah, what do you do// \\
\hline 23 & Jo: & //yeah what do you do when you are sad? \\
\hline 24 & Ana: & If I'm sad, I'll play badminton and I'll smash \\
\hline $\begin{array}{l}25 \\
26\end{array}$ & $\begin{array}{l}\text { Jo: } \\
\text { June: }\end{array}$ & $\begin{array}{l}\text { I'll answer for June. June }<\text { Ana LAUGH }>\text { she said, she will eat a lot of things } \\
\text { No, I meant you }\end{array}$ \\
\hline 27 & Ana: & I can answer for you. when you are sad \\
\hline 28 & June: & No he will ask us for steamboat \\
\hline 29 & Sue: & Yeah \\
\hline
\end{tabular}

In Excerpt 1, the group explored the horizons of three planes. First, they attempted to begin their discussion by sharing personal recalling of factual detail in the short story. Ana began the discussion by asking about the guitar and what it may symbolise as indicated in Line 1. Next, in Line 16, June began to contemplate and relate the guitar to a literary device. Further down, beginning in Line 21, the excerpt demonstrates another important pattern in exploring horizons of possibilities. After exploring the possible symbols of the guitar, the group began to reflect and make personal connections to the situation when June asked the group what they would do if they feel sad. 
The start of the discussion resembles a typical move in most class discussions that focus on factual details and the identification of literary devices. The attempt was possibly adopted as a customary way of dealing with texts together in classroom discussions that centre on getting the right facts for comprehension purposes. This typically resembles the convention in a scientific way of looking at texts where the initial focus centres on building an understanding of details. The learners may have thought that they should follow this common discourse convention through observing instructors orchestrate class discussions about literature.

Nevertheless, they were quickly able to progress into contemplating possible personal interpretations of the symbol of the guitar when given the freedom to navigate the group interaction without interruption or facilitation of the instructor. The group also attempted to explore other horizons of possibilities. They explored personal connections to the text that went beyond the imaginary world when they began exploring what they would do when they feel sad. The question that June asked was crucial in stimulating a collective effort to explore and activate personal engagement to the imaginary world. Through the literary way of thinking, critical, creative, and imaginative thinking processes were made evident.

The next excerpt was taken from Group Two that also consisted of four participants. The discussion centred on the existence of the grandfather in the short story. In doing so, like Group One, they specifically recalled for specific information about the grandfather and the grandfather's relation to other characters in the short story.

EXCERPT 2. Discussion by Group Two on the existence and function of a character

$\begin{array}{lll}1 & \text { Sam: } & \begin{array}{l}\text { Actually I don't quite understand about the situation where his grandma tells about his } \\ \text { grandma and grandpa. Can anyone tell me what happened? }\end{array} \\ 2 & \text { Arif: } & \text { Ok, fact number one, there's no grandpa } \\ 3 & \text { Sam: } & \text { It mentioned// } \\ 5 & \text { Lin: } & \text { //yeah, it mentioned. it mentioned about the grandpa } \\ 6 & \text { Arif: } & \text { I thought no } \\ 7 & \text { Aeen: } & \text { No, I didn't come across the word grandpa, I just came across the word grandma// } \\ 8 & \text { Lin: } & \text { Grandpa and grandma. Here ...here } \\ 9 & \text { Arif: } & \text { Huh? Oh, maybe this is about the grandpa the relationship between grandpa and grandma } \\ 10 & \text { Lin: } & \text { No, it's about here, aa } \\ 11 & \text { Arif: } & \text { Ya ya ya ya. It is... it is about the relationship between the } \\ 12 & \text { Lin: } & \text { Between? } \\ 13 & \text { Sam: } & \text { I think we need to read the story all again } \\ 14 & \text { Lin: } & \text { No, she's comparing Joshua with his grandpa. His grandmother said that aa Joshua, you are } \\ 15 & \text { Deen: } & \text { It means that the grandpa is not here. Just like a flashback } \\ 16 & \text { Lin: } & \text { Yeah. Yeah. He's there } \\ 17 & \text { Deen: } & \text { His grandmother is comparing Joshua and his grandfather quite similar, right? } \\ 18 & \text { Arif: } & \text { So it's not grandpa, it's just description in the story. } \\ 19 & \text { Deen: } & \text { Actually the grandmother, it is just a flashback. }\end{array}$

You see, I'm not quite sure but in this story it stated that the grandpa the grandmother right, the character will appear when Joshua is in depression he will think back, refresh mind, going back to the past about the person that would take care of him, the person who will take care of Joshua is only his grandmother 
In general, the excerpt can disclose important evidence that many groups were able to process. First, when the group was given the chance to discuss the short story independently, the platform had made the participants feel at ease to openly express and admit personal doubts or misunderstandings about their experience in reading about the textual world. To illustrate, in Line 1 Sam willingly confessed that he was not sure about the existence of the grandfather. Second, the confession had triggered the others to recall facts concerning the existence of this character. Although the issue was rather straightforward, the group readily made the effort to scrutinise the text to get the right evidence in the short story. As shown in Line 13, Sam felt that it was important for the group to reread the short story.

In exploring horizons of possibilities about the character, the group also became more critical and creative. They observed and discussed the personal evaluation of possible themes and probable use of a literary device like a flashback. Arif contemplated in Line 9 that one possible theme is the relationship between the grandfather and grandmother. In Line 14, Lin suggested a comparison be made concerning how the grandmother reacted to Joshua and the grandfather. Upon realising that the grandfather's character does not exist, Deen in Line 15 suggested the use of flashback as a literary device that clarified the group's exploration of the role of the grandfather. As demonstrated in the excerpt, it could be deduced that the participants perceived the need to initiate discussions by fact-finding before moving into exploring horizons of possibilities. The excerpt demonstrates productive literary thinking processes involving critical and creative thinking.

The next excerpt by a group of three participants centralised a Chinese proverb and how the Chinese proverb is associated to a character, Sarah, Joshua's mother. The group explored the connection between the proverb and Sarah. It was found that they were pleased to discuss and suggest how Sarah could have handled issues with her weight:

EXCERPT 3. Discussion by Group Three on exploring character's weight problem

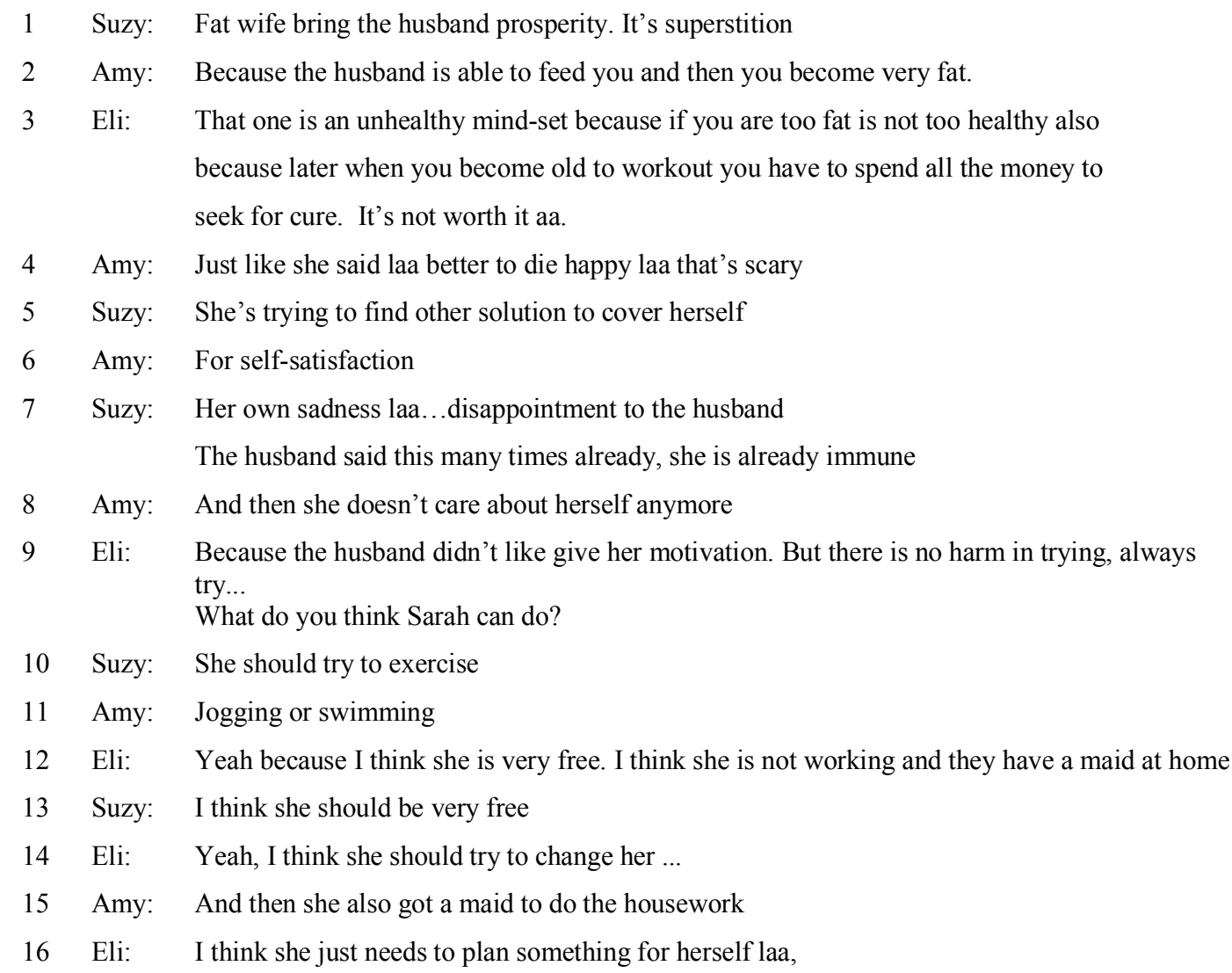




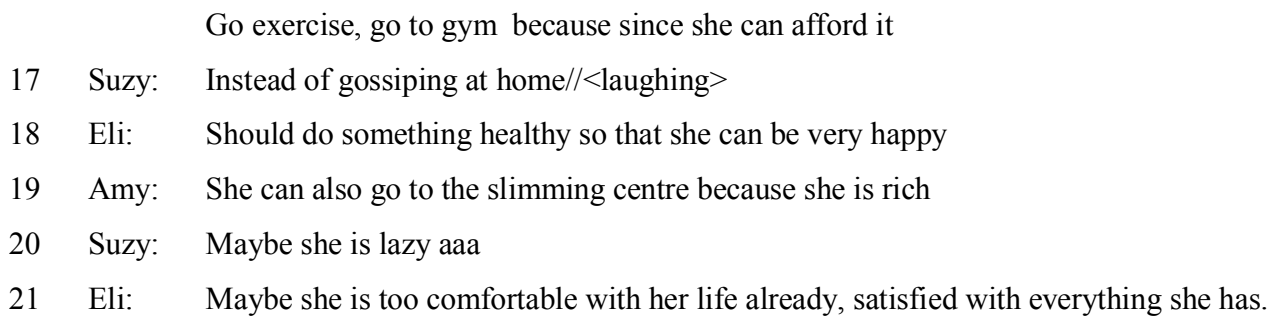

Initially, the group was capable of not only contemplating personal interpretations of how the proverb may be directly related to the character Sarah in the short story, but they were also able to explore horizons of possibilities about how the proverb may reflect what the character feels about herself. At this point, they were critical as they speculated and evaluated probable attitudes and feelings that Sarah might have. This is where exploring horizons of possibilities in literature could help open opportunities for learners to practise using both the scientific and the literary ways of thinking in the meaning-making process. Unlike exploring factually based texts that emphasise the importance of objective scientific reasoning, this excerpt illustrates that the participants were free to contemplate, make guesses, display creativity, and foster imagination in exploring probable thoughts, feelings and values concerning Sarah.

The discussion also showed very strong engagement and living through experience (Rosenblatt, 1978); the group was able to move quickly into and beyond the imaginary world, utilising personal background knowledge and experiences in expressing their critical views. As such, they were able to discover horizons of possibilities that touched on possible measures to help Sarah. Their engagement into different horizons of possibilities about Sarah demonstrated profound marriage of the scientific and literary ways of thinking.

Excerpt 4 depicts another fascinating exploration of horizons of possibilities by Group Four. The group of four participants discussed their connection and evaluation of the ending of the short story. Based on the plot, both of Joshua's parents met with a fatal accident.

EXCERPT 4. Discussion by Group Four on extending the imaginary world

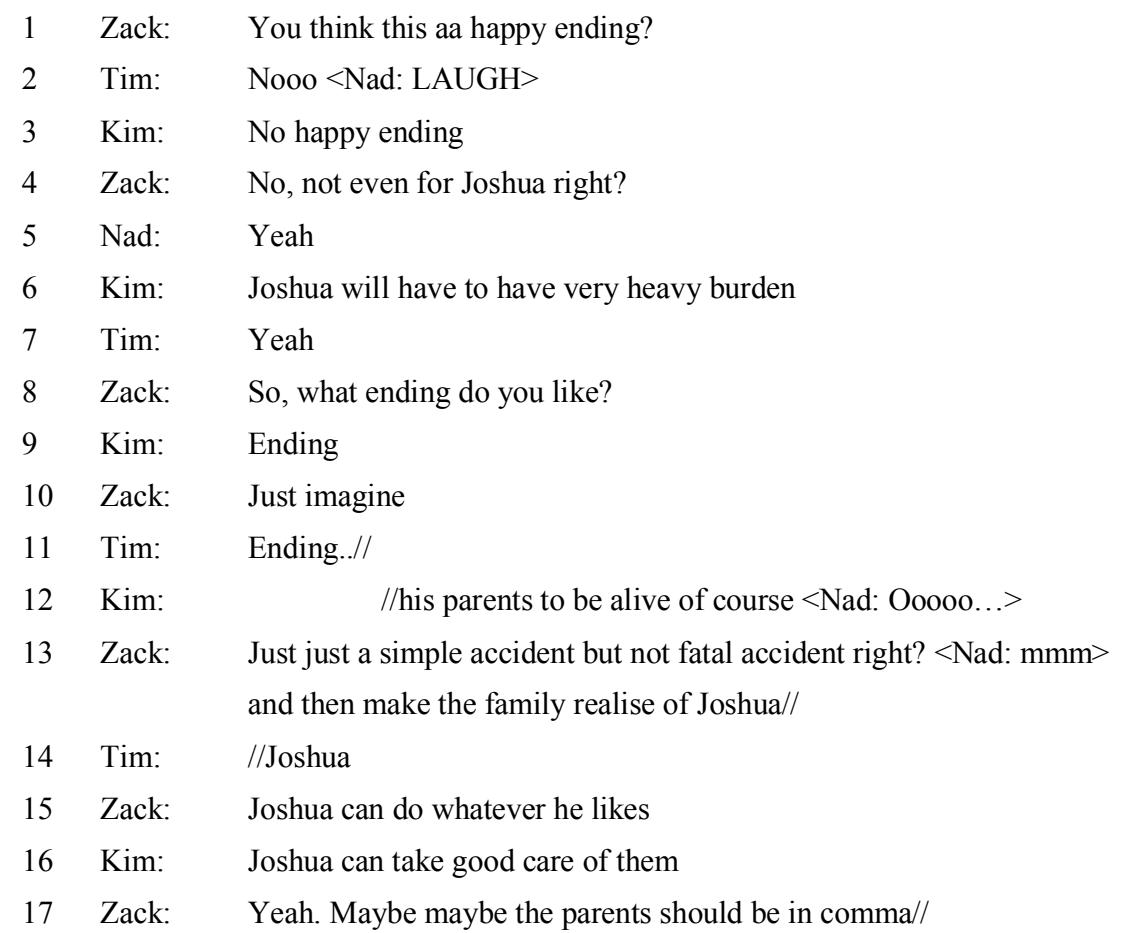




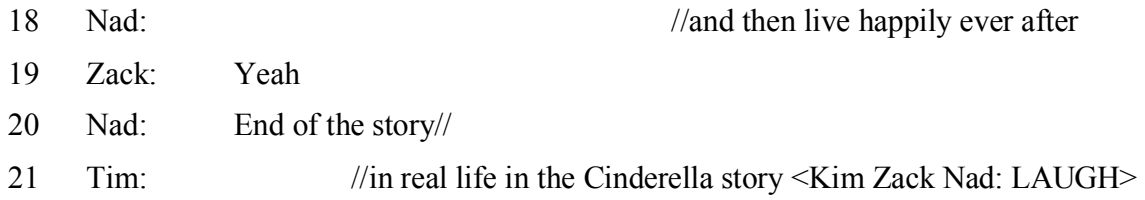

In the discussion, Zack asked what the group thought about the tragic ending. This highlights the strength of the literary way of thinking. In attempting to envision probable prospects for alternative endings for the short story, the group went beyond information recognised in the plot. They attempted to explore other more appealing endings for the imaginary world.

In wanting a more agreeable ending for the plot, the group focused on the character, Joshua and how the group related to Joshua. For context, Joshua belonged to the same age group, raised within the same cultural context and studied as a second-year university student. Not only were they ready to explore different horizons of possibilities of how the ending should take place, but they were also eager to discuss horizons of possibilities of how the short story should progress for Joshua to become a happier character. Evidently, in exploring horizons of possibilities through the peer-led group discussion, the participants were productive and engaged in deep thinking processes that involved critical, creative, and imaginative thinking as they attempted to improvise the short story. In addition, the group also showed the personal connection to Joshua's character since they tried to depict his future that went beyond the imaginary world. This generative state distinctly exemplifies the literate mind in the making where the participants collectively attempted to change and extend the plot of the short story according to what they envisioned, hoped, and chose.

\section{DISCUSSION}

The findings essentially revealed several interesting phenomena about the literacy aptitudes of the participants. Among the things realised in this study were that in exploring horizons of possibilities of the short story, the participants were productive in using different ways of thinking involving critical, creative, and imaginative thinking. At the same time, they were personally engaged in building meaning. Through the group interactions, the participants shared personal recalling of facts or literary devices, contemplated personal interpretations of meaning and, discussed the personal evaluation of the text using the efferent stance. At the same time, they utilized the aesthetic stance as they expressed doubts or misunderstandings, made personal connections or extended the imaginary world. In doing so, they explored meaning from multiple points of view, participated and discussed possible horizons of possibilities and were immersed in a living through experience with the imaginary world and beyond. According to Turner (1996),

$$
\begin{aligned}
& \text { often a short story will contain no overt mark that it stands for anything but what it purports to represent, and } \\
& \text { yet we will interpret it as projecting to a much larger abstract narrative, one that applies to our own specific } \\
& \text { lives, however far our lives are removed from the detail of the story. } \\
& \text { (p. 7) }
\end{aligned}
$$

This shows that the groups could engage in different thinking processes. They combined facts in the textual world using horizons of possibilities, the literary way of thinking.

The freedom to explore horizons of possibilities encouraged the groups to evaluate, share, contemplate, and listen to multiple interpretations concerning the different course of actions as demonstrated in the short story. For instance, the excerpts from Group Three and Four showed that the groups worked hard to suggest and consider different points of view about helping the character, Sarah, with her physique. Also, the participants were able to recreate a 
better ending for the short story and forecast a bright and happy future for the character, Joshua. Clarke \& Whitney (2009, p. 532) asserted that when the opportunity is given to view "different vantage points - especially the ones that are not heard from as often - students can see how power and perspectives can silence one of the two sides in every story and influence how we interpret history." In fact, Rosenblatt (1995, p. 215) suggested that "new technical, personal and social insights may ultimately lead to a revision of his [learner's] original interpretation and judgement and may improve his equipment for future response to literature." The group interaction was capable of influencing and extending personal visions, thoughts, ideas, and senses about the imaginary world as the participants learned and supported one another in exploring horizons of possibilities.

Furthermore, when the participants discussed the short story independently, they showed enthusiasm to contribute and support the recalling and discovering of other factual details (Adler \& Rougle, 2005). This was obvious in Group Two's discussion about the existence of the grandfather's character. Through the efferent stance, the group consciously examined the short story to convince themselves about the character's existence and to help one another explore horizons of possibilities about if and when he exited. Rosenblatt (1978) explained,

\footnotetext{
A reader who has been moved or disturbed by a text often manifests an urge to talk about it. He likes to hear others' views....as we exchange experiences... we may help one another to attend to words, phrases, images, scenes, that we have overlooked or slighted. We may be led to reread the text and revise our own interpretations.

The findings clearly demonstrated that when exploring horizons of possibilities, participants disclosed very favourable attitudes and confidence in thinking and giving opinions about the short story. Many tried to discover and explain personal understandings in detail and made efforts to help and encourage their group to explore personal understandings or interpretations through exploring horizons of possibilities. As no instructor was present to navigate or scaffold the interactions, participants had to depend either on their background knowledge and past experiences or their group members in exploring, making sense and thinking about different issues and explanations about the short story (Chi, 2012). The chance to participate and become responsible for their learning had somehow driven them to search, grapple and consider potential meanings among themselves.

Moreover, when the groups openly made personal guesses, voiced private thoughts and doubts or asked specific questions, the circumstances showed that the participants were contented. They probably felt that it would not be an inconvenience if they had understood the short story differently or were unable to identify and provide the kinds of answers that the instructor would normally expect in classroom discussions of literary texts.

To illustrate, although Groups One and Two tried to follow the class discussion discourse structure by finding factual details using the scientific way of thinking, everyone in both groups seemed to willingly and openly express misunderstandings and doubts as they explored horizons of possibilities collectively. The participants were more comfortable participating and contributing ideas about multiple possibilities without worrying if the ideas can be supported using factual evidence in the short story. They may have felt compelled to collectively become responsible for their own meaning-making.

The findings also showed that when exploring horizons of possibilities, the participants had the opportunity to adopt the aesthetic stance when they shared their connections in the form of inner thoughts, feelings and involvements with the short story. This can be observed in the second half of the excerpt in Group One's discussion from Line 20 onwards as they discussed the feelings of the character Joshua concerning their own lives. This may not be common in most class discussion structures as most of the time students do not get to openly share and 
learn about personal connections and feelings in reading literary texts. Ordinarily, the instructor would be the one navigating the discussion and students would most of the time rely on the factual details or interpretations supplied to them. According to Rosenblatt (1995), the chance to openly share one's living through experience helps the learner

\footnotetext{
understand his own preoccupations and assumptions better. He considers whether he has overlooked elements in the text. He thus becomes more aware of the various verbal clues - the diction, the rhythmic pattern, structure and symbol - and develops or deepens his understanding of concepts.

Group One wandered and shared personal feelings and involvement through the literary way of thinking. As such, their actions signify an engaging and meaningful learning experience. This exemplifies a vital process in nurturing the literate mind (Johnston, 2020).

Through the literary way of thinking, the excerpts further showed that the freedom to express and listen to different horizons of possibilities advanced their engagement, creativity and imagination about the short story. For example, when Group Four evaluated the ending of the short story, they voiced their dissatisfaction about the ending of the plot which led them to improvise the short story to create their most ideal imaginary world as Kim wished for "real life in the Cinderella story." Apparently, in improvising the imaginary world, the group was able to venture into the aesthetic stance. They moved into, lived through and went beyond what was apparent in the short story.

\section{CONCLUSION AND RECOMMENDATION}

In presenting how the literate mind can be nurtured, this article described the various ways of how the term literacy can be defined. Then, it was proposed that the established scientific way of thinking be incorporated into the literary way of thinking through group interactions. In examining this alternative way of thinking, the idea of exploring horizons of possibilities was introduced.

The findings showed that exploring horizons of possibilities through group interactions demonstrated the strength and value of the literary way of thinking for the development of the literate mind. Among the things demonstrated was that through exploring the horizons of possibilities, the mind can explore multiple points of view as participants shared personal recalling of facts or literary devices, contemplated personal interpretations of meaning, and discussed the personal evaluation of the text. Meanwhile, the participants also expressed personal doubts or misunderstandings, made personal connections to the textual world, or extended the imaginary world. This shows that they were personally engaged in a living through experience with the imaginary world and beyond. The freedom to explore horizons of possibilities through group interactions exhibited qualities of the literate mind that nurtures a constructive and attractive learning experience for literary thinkers.

While the scientific way of thinking has been established to be the essence of advanced literacy skills dominating the discussion patterns of many classrooms across disciplines, this study demonstrated that the literary way of thinking through group interactions supports the advancement of literacy for the literate mind. First, when given the freedom to explore horizons of possibilities, the participants had the opportunity to engage in different thinking processes such as critical, creative, and imaginative thinking in becoming literary thinkers. Second, the opportunity to engage in group interactions promoted personal engagement in the learning process. In other words, the exploration of horizons of possibilities through group interactions encouraged participation, engagement and the ability to use both literary and scientific ways of thinking in exploring literature. 
To nurture literacy for the literate mind, time as well as opportunity for learners to engage in exploring different ways of thinking using both the efferent and aesthetic stances are indispensable. Activities that encourage interactions such as peer-led group discussions should be carried out for learners to explore and examine their understandings, interpretations as well as critical views about literature. Meanwhile, engaging in exploring horizons of possibilities through group interaction unlocks different thinking processes. This generative course not only promotes the use of critical, creative, and imaginative thinking but also personal engagement that ensures the shaping of well-rounded literate minds.

\section{ACKNOWLEDGMENT}

The researchers would like to thank Universiti Teknologi Malaysia for generously funding this research project and for the support in the publication of this journal article. This study was based on a research project entitled Orchestrating Meaning in Group: Insights into StudentDriven Literature Instruction (Q.J130000.2653.18J28 PY/2019/01727).

\section{REFERENCES}

Adler, M. \& Rougle, E. (2005). Building literacy through classroom discussion: Research-based strategies for developing critical readers and thoughtful writers in middle school. New York: Scholastic Inc.

Almasi, J. F. (1995). The nature of fourth graders' sociocognitive conflicts in peer-led and teacher-led discussions of literature. Reading Research Quarterly. Vol. 3(3), 314-35. https://doi.org/10.2307/747620

Aukerman, M., Johnson, E.M., \& Schuldt, C.S. (2017). Reciprocity of student and teacher discourse practices in monologically and dialogically organised text discussion. Journal of Language and Literacy Education. Vol. 13(2), 1-52. Retrieved September 2, 2020 from http://jolle.coe.uga.edu/wpcontent/uploads/2015/04/Aukerman JoLLE2016 243.pdf

Barnes, D. (2008). Exploratory talk for learning. In N. Mercer, \& s. Hodgkinson (eds.) Exploring talk in school (pp. 1-6). London: Sage Publications.

Barnes, D. (2010). Why talk is important. English Teaching: Practice and Critique. Vol. 9(2), 7-10. http://education.waikato.ac.nz/research/files/etpc/files/2010v9n2art1.pdf

Barton, D. (2007). Literacy: An introduction to the ecology of written language. Oxford: Blackwell.

Beach, R., Enciso, P., Harste, J., Jenkins, C., Raina, S.A., Rogers, R., Short, K.G., Yoo Kyung Sung, Wilson, M. \& Agbaw, V.Y. (2009). Aiming for the future: Cultivating a sense of the possible. In National Reading Conference Yearbook. Vol. 58, 129 -143. Retrieved February 14, 2020 from https://www.coe.arizona.edu/sites/default/files/critical_content analysis-nrc.pdf

Bruner, J. (1986). Actual Minds, possible Worlds. London: Harvard University Press.

Chi, F. (2012). Searching for intertextual connections in small group discussion. Journal of Research in Reading. Vol. 35(3), 251-266. https://doi.org/10.1111/j.1467-9817.2010.01457.x

Cho, K.S \& Krashen, S. (2020). Why don't EFL students read more? Because "we are tested on what we read in class." In Language and Language Teaching. 50-53. Retrieved September 2, 2020 from http://publications.azimpremjifoundation.org/2190/1/8 Why\%20don\%27t\%20EFL\%20students\%20rea d\%20more $\% 20$ because $\% 20$ we $\% 20$ are $\% 20$ tested $\% 20$ on $\% 20$ what $\% 20$ we $\% 20$ read $\% 20$ in $\% 20$ class.pdf

Clarke, L. W. \& Whitney, E. (2009). Walking in their shoes: Using multiple-perspectives texts as a bridge to critical literacy. The Reading Teacher. Vol. 62(6), 530-534. Retrieved February 14, 2020 from https://eric.ed.gov/?redir=http\%3a\%2f\%2fdx.doi.org\%2f10.1598\%2fRT.62.6.7

Daniels, H. (2002). Literature circles: Voices and choice in book clubs and reading groups. Portland: Stenhouse Publishers.

Douglas, K., Barnett, T., Poletti, A., Seaboyer, J. \& Kennedy, R. (2015). Building reading resilience: re-thinking reading for the literary studies classroom. Higher Education Research \& Development. Vol. 35(2), 254266. https://doi.org/10.1080/07294360.2015.1087475

Friend, L. (2017). IRE and content area literacies: A Critical Analysis of Classroom Discourse. The Australian Journal of Language and Literacy. Vol. 40(2), 124-134.

Gough, P. B. (1995). The new literacy: Caveat emptor. Journal of Research in Reading. Vol. 18(2), 79-86. https://doi.org/10.1111/j.1467-9817.1995.tb00074.x

Harste, J.C. (March, 2003). What do we mean by literacy now? Voices from the Middle. Vol. 10(3), 8-12. Retrieved February 14, 2021 from https://library.ncte.org/journals/vm/issues/v10-3 
Heller, M. F. (2007). Telling stories and talking facts: First graders' engagements in a nonfiction book club. The Reading Teacher. Vol. 60(4), 358-369. Retrieved January 14, 2020 from https://www.jstor.org/stable/i20204469

Howard, P. (2010). How literature works: Poetry and the phenomenology of reader response. Phenomenology \& Practice. Vol. 4(1), 52-67. Retrieved February 14, 2021 from https://journals.library.ualberta.ca/pandpr/index.php/pandpr/article/view/19827/15345

Howe, A. (2013). Developing the Talking School: Action research at Qxford Spires and St Mark's Church of England Academies. 1-36. Retrieved February 2, 2020 from https://www.oxfordspiresacademy.org/download/documents/r-talking-schools-report-2013-1.pdf

Johnston, P.H. (2020). Engaging literate minds: Developing children's social, emotional and intellectual lives. Maine: Stenhouse Publishers.

Karolides, N.J. (2020). Reader Response in Elementary Classrooms. New York: Routledge. Retrieved July 31, 2020 from https://www.taylorfrancis.com/books/e/9781315045061

Khamkhong, S. (2018). Developing English L2 critical reading and thinking skills through the PISA reading literacy assessment Framework: A case study of Thai EFL learners. $3 L$ : The Southeast Asian Journal of English Language Studies. Vol. 24(3): 83-94. http://doi.org/10.17576/3L-2018-2403-07

Langer, J.A. (1986). Children reading and writing: Structures and strategies. New Jersey: Ablex Pub. Corp.

Langer, J.A. (2002). The literate mind. (ED 476 824). Educational Resources Information Center. Retrieved June 14, 2021 from https://files.eric.ed.gov/fulltext/ED476284.pdf

Langer, J.A. (2011). Envisioning Literature: Literary understanding and literary instruction. (2Ed.). New Jersey: Teachers College Press, Teachers College, Columbia University.

Marlia Puteh, Zuhana Mohd Zin \& Ihsan Ismail. (2016). Reading Performance of Malaysian Students across Gender in PISA 2012. 3L: The Southern Asian Journal of English Language Studies. Vol. 22(2), 109121. http://doi.org/10.17576/3L-2016-2202-08

Nystrand, M. (2006). Research on the role of classroom discourse as it affects reading comprehension. Research in the Teaching of English. Vol. 40(4), 392-412. Retrieved July 24, 2020 from https://www.jstor.org/stable/40171709?refreqid=excelsior\%3A801ff5ef5b39cc7449095d7d906a30fd

Reynolds, T. (2019). Like a conductor: Whole-class discussion in English classrooms. English Teaching: Practice \& Critique. Vol. 18(4), 478-491. Retrieved September 25, 2020 from https://www.emerald.com/insight/content/doi/10.1108/ETPC-04-2019-0053/full/html

Rosenblatt, L.M. (1978). The reader, the text, the poem: The transactional theory of the literary work. Illinois: Southern Illinois University Press.

Rosenblatt, L.M. (1988). Writing and reading: The transactional theory. (416). Bolt Beranek and Newman Inc. Retrieved June 10, 2021 from https://files.eric.ed.gov/fulltext/ED292062.pdf

Rosenblatt, L.M. (1993). The transactional theory: Against dualisms. College English. Vol. 55(4), 377-386.

Rosenblatt, L.M. (1995). Literature as exploration. New York: Modern Languages Association.

Rosenblatt, L.M. (2005). Meaning making with the text: Selected essays. Portsmouth: Heinemann.

Rosenberg, J. (2019). Literacy... from the beginning in parents' league review. Retrieved September 2, 2020 from https://www.parentsleague.org/sites/default/files/LiteracyFromBeginning.pdf.

Simpson, A., Mercer, N. \& Majors, Y. (2010). Editorial: Douglas Barnes revisited: If learning floats on a sea of talk, what kind of talk? And what kind of learning? English Teaching: Practice and Critique. Vol.9(2), $1-6$.

Smith, V. (2004). Empowering teachers: Empowering children? How can researchers initiate and research empowerment? Journal of Research in Reading. Vol. 27(4), 413-424. http://doi.org/10.1111/j.14679817.2004.00243.x

Soter, A.O., Wilkinson, I.A.G., Murphy, P.K., Rudge, L., Reninger, K. \& Edwards, M. (2009). What the discourse tells us: Talk and indicators of high-level comprehension. International Journal of Educational Research. Vol. $\quad 47, \quad 372-391 . \quad$ Retrieved July 20, 2020 from https://eric.ed.gov/?redir=http\%3a\%2f\%2fdx.doi.org\%2f10.1016\%2fj.ijer.2009.01.001

Tan, S.Y., Tee, M.Y. \& Moses, S. (2017). Persistent monologicality amidst variation in teachers' questioning practices in Malaysian English language classrooms. Journal of Asia TEFL. Vol. 14(4), 621-637. $\begin{array}{llll}\text { Retrieved June } & 20, & 2020 & \text { from }\end{array}$ https://search.proquest.com/openview/77c75933587f279c651b64d52a06c664/1?pqorigsite $=$ gscholar\&cbl $=4424407$

Tatum, A.W. (2019). Meaningful literacy and life exchanges with text: An uncommon trilogy. Journal of Adolescent \& Adult Literacy. Vol. 62(5), 579-582. http://doi.org/10.1002/jaal.931

Teo, P. (2019). Teaching for the $21^{\text {st }}$ century: A case for dialogic pedagogy. Learning, Culture and Social Interaction. Vol. 21, 170-178. http://doi.org/10.1016/j.lcsi.2019.03.009

Turner, M. (1996). The literary mind: The origins of thought and language. New York: Oxford University Press. 
Tytler, R. \& Prain, V. (2010). A framework for re-thinking learning in science from recent cognitive science perspectives. International Journal of Science Education. Vol. 32(15), 2055-2078. https://doi.org/10.1080/09500690903334849

United Nations Educational, Scientific and Cultural Organisation. (2006). Education for all: Literacy of life. Education for All Global Monitoring Report UNESCO. Retrieved January 18, 2021 from https://unesdoc.unesco.org/ark:/48223/pf0000141639

Yeoh, G.S. (2009). Coffee Break Talk. Pelanduk Publications.

Zuhana Mohd Zin, Wong, B. E. \& Shameem Rafik-Galea. (2014). Critical reading ability and its relation to L2 proficiency of Malaysia ESL learners. 3L: The Southeast Asian Journal of English Language Studies Vol 20(2): 43 - 54. http://dx.doi.org/10.17576/3L-2014-2002-04 